\title{
OBITUARY
}

\author{
RAJASEVASAKTA V. SUBRAHMANYA IYER, OF MYSORE, INDIA
}

ON Christmas Day, 1949, Mr. Subrahmanya Iyer passed away at the ripe age of 81 . Born at Salem in 1869 , he bad bis early education in Bangalore and after passing the Matriculation Examination he joined the Madras Christian College. Mr. Iyer early felt the call of philosophy under the inspiring teaching of Dr. Charles Cooper, who kindled in him "a passionate love for metaphysics." He also studied Physiology under Dr. J.-R. Henderson. He then felt attracted by Thomas Huxley and Herbert Spencer and so he went on to study Physics and Mathematics under Dr. John Cook of Central College, Bangalore. He started his life in the Education Department of Mysore, but with the adventurous spirit of youth he soon preferred to accept a professorship in Physics in a college at Agra. He there met Chamarajendra Wodiyar, Maharaja of Mysore, who was struck by his personality and tempted him back to Mysore service. After serving as teacher for a few years he soon became Head Master of several schools and as Head Master Mr. Iyer made a name for himself. Later he worked as Assistant to the Inspector-General of Education in Mysore and as Secretary of the Board of Education, a branch of the Mysore Economic Conference. In I920 he was appointed Regis. trar of Mysore University and in 1926 he retired.

It was during his headmastership at Shimoga and Chickmagalur that there occurred the most outstanding incident in his life: his contact with the then Sringeri Swami, Narasimha Bharati. Sringeri Mutt was originally founded by the great Sankarcharya in the eighth century and the heads of the Mutt through successive centuries have enjoyed immense prestige and power all over India and particularly in South India. Narasimha Bharati was an exceptional scholar and cast his spell over Mr. Subrahmanya Iyer. Every vacation year after year came to be spent by him with the great Swami and as a result of it Mr. Iyer emerged as a confirmed Advaitin and a devoted follower of Sankara. It was an irony of fate that he never got a chance of teaching philosophy in a college or a university, but it is all the more creditable that he kept up his interest in philosophy, read voraciously every book on philosophy, Eastern or Western, that came his way, and like Socrates delighted in button-holing kindred spirits into endless philosophic discussion. His contact with the members of the Philosophy Department of Mysore University was a very living one.

It was after his retirement that he came more and more into personal contact with His late Highness Krishnaraja Wodiyar IV, Maharaja of Mysore, whose deep philosophic interest made him recognize the philosophic worth of Mr. Iyer, and Mr. Iyer practically became Reader in Philosophy to His Highness. Out of gratitude to His Highness Mr. Iyer endowed "Shri Krishnarajendra Silver Jubilee Lectureship" in the University of Mysore. The subject of the lecture has to be on Science and Humanities in alternate years. It was this contact that gave birth to the very fine idea of starting a Study Circle in the Ramakrishna Mission at Mysore. His Highness undertook the responsibility of maintaining a number of the members of the Mission year after year to study philosophy under Mr. Iyer. At long last the chance came to Mr. Iyer to be a teacher of philosophy. Members of the Philosophy Department of Mysore University gave lectures on European Metaphysics and Ethics and Sociology, and the idea of the Maharaja that the Swamis of the Ramakrishna Asharama should not just be learned on Indian lines, but should also be versed in Western philosophy, came to be abundantly realized.

In 1936 he accompanied the late Maharaja of Mysore to Europe and in 1937 he was again sent to Paris to attend the International Phlosophic Conference held at Paris. This visit was responsible for one great change in Mr. Iyer's outlook. As a devoted follower of Sankara it was his habit to be copiously quoting from Sankara. After his visit to Europe he gave up this habit and was more inclined to argue out problems in an impersonal way, though the old bias and the old loyalties never left him.

\section{His Philosophy}

What was his philosophic teaching? He was a confirmed Advaitin, believed in the ultimate reality of Brahman and Brahman only: nirguna or without qualities. He accepted the doctrine of maya, which is usually translated as illusion, but Mr. Iyer was content to speak of it as phenomenal and to this extent as unreal. His originality lay in trying to prove the truth of $A$ dvaita on the basis of Western science. He expatiated on the disinterestedness of philosophic studies and the importance of the scientific method even in philosophy. His favourites in Western philosophy were Hume and Bradley and also Kant. It was his confirmed belief that "no philosophy can live today in anything but a fool's paradise, unless it ventures out into the open but biting air of critical reason as natural science does." It followed from this that he had no faith in mysticism or religion. He accepted the pragmatic value of religion for 9,999 out of 10,000 , but to the select among his audience he made no secret that he had nothing but contempt for religion as truth. He thought that Western philosophers had not devoted themselves to the pursuit of Truth, that they had not raised this fundamental question and hence they had not come up to the level of philosophic thought in India. But let it be remem. bered that when he spoke of the superiority of Indian philosophy, he always meant thereby Advaita, for he had just a bare patronizing tolerance for all Indian thought other than $A d v a i t a$. There were palpable lacunae in his thought, and many, including the present writer, could not accept his conclusions, but none who came into contact with him failed to breathe a pure metaphysical air or to be impressed by his earnestness and worth as a philosophic thinker of the highest order.

Mr. Iyer has died full of years, leaving behind him a son and three daughters and a very wide circle of friends and admirers.

A. R. WADIA. 